Article

\title{
Investigation of the Effect of Solar Ventilation on the Cabin Temperature of Vehicles Parked under the Sun
}

\author{
Hani Al-Rawashdeh ${ }^{1}{ }^{1}$, Ahmad O. Hasan ${ }^{1}$, Hazem A. Al-Shakhanbeh ${ }^{1}$, Mujahed Al-Dhaifallah ${ }^{2,3} \mathbb{D}$, \\ Mohamed R. Gomaa 1,4 (D) and Hegazy Rezk 5,6,*(D)
}

1 Mechanical Engineering Department, Faculty of Engineering, Al-Hussein Bin Talal University, Ma'an 71111, Jordan; hani_raw@yahoo.com (H.A.-R.); ahmad_almaany@yahoo.com (A.O.H.); hazem_alhamaeda@hotmail.com (H.A.A.-S.); Behiri@bhit.bu.edu.eg (M.R.G.)

2 Control and Instrumentation Engineering Department, King Fahd University of Petroleum \& Minerals, Dhahran 31261, Saudi Arabia; mujahed@kfupm.edu.sa

3 Interdisciplinary Research Center (IRC) for Renewable Energy and Power Systems, King Fahd University of Petroleum \& Minerals, Dhahran 31261, Saudi Arabia

4 Mechanical Engineering Department, Benha Faculty of Engineering, Benha University, Benha 13518, Egypt

5 College of Engineering at Wadi Addawaser, Prince Sattam Bin Abdulaziz University, Al-Kharj 11942, Saudi Arabia

6 Electrical Engineering Department, Faculty of Engineering, Minia University, Minia 61519, Egypt

* Correspondence: hr.hussien@psau.edu.sa

Citation: Al-Rawashdeh, H.; Hasan, A.O.; Al-Shakhanbeh, H.A.;

Al-Dhaifallah, M.; Gomaa, M.R.; Rezk, H. Investigation of the Effect of Solar Ventilation on the Cabin Temperature of Vehicles Parked under the Sun. Sustainability 2021, 13, 13963. https:// doi.org/10.3390/su132413963

Academic Editor: Akbar Maleki

Received: 23 October 2021

Accepted: 12 December 2021

Published: 17 December 2021

Publisher's Note: MDPI stays neutral with regard to jurisdictional claims in published maps and institutional affiliations.

Copyright: (c) 2021 by the authors. Licensee MDPI, Basel, Switzerland. This article is an open access article distributed under the terms and conditions of the Creative Commons Attribution (CC BY) license (https:/ / creativecommons.org/licenses/by/ $4.0 /)$.

\begin{abstract}
During hot days, the temperature inside vehicles parked under the sun is very high; according to previous studies, the vehicle cabin temperature can be more than $20{ }^{\circ} \mathrm{C}$ higher than the ambient temperature. Due to the greenhouse effect, the heating that occurs inside a vehicle while it is parked under the sun has an impact on energy crises and environmental pollution. In addition, the increase in the temperature inside the cabin will have an effect on the dashboard and plastic accessories and the leather on the seats will age rapidly. The ventilation of solar energy from the cabin of a vehicle parked under the blazing sun has received a great deal of attention. The present study was conducted to utilize a renewable energy system to operate the ventilation system through a novel portable ventilation system powered by solar energy. Experimental results were obtained for a vehicle with and without the solar ventilation system. The results indicate that the maximum daily average difference in temperature during the experimental tests between the cabin of the car and the atmospheric temperature with and without the solar ventilation system was $7.2{ }^{\circ} \mathrm{C}$ and $20.6{ }^{\circ} \mathrm{C}$, respectively. With and without the usage of the system, the minimum average difference in temperature between the automobile's cabin and the atmospheric temperature was $6.2{ }^{\circ} \mathrm{C}$ and $17.6{ }^{\circ} \mathrm{C}$, respectively. The results indicate that the proposed system is effective and that the thermal comfort inside the vehicle's cabin improved when the vehicle was parked under the hot sun. Therefore, this system helps to protect human bodies, conserve energy, protect the environment, protect the vehicle's cabin, and provide a comfortable environment.
\end{abstract}

Keywords: ventilation; greenhouse effect; photovoltaic panel; thermal comfort level

\section{Introduction}

Due to the global energy crisis and environmental pollution, the focus these days is on electrical vehicles instead of traditional vehicles, as they help to reduce emissions and save energy [1,2]. Vehicles are important to the transportation sector within our society; however, the consumption of fossil fuels has many disadvantages, including smog emissions and global warming, that require the automotive industry to provide new energy sources and conduct research focused on electric vehicles to overcome these disadvantages [3]. Researchers have developed many ways to harvest energy from the environment, such as vibration energy [4,5] and different categories of energy-harvesting systems, including mechanical, thermoelectric, piezoelectric, wind energy, and solar energy [6-13], which can 
help to reduce emissions [14-16]. Many countries are focused on solar energy, because solar energy is a clean and renewable type of energy that can be used to provide electricity and heat [17]. Many researchers have concentrated on the use of solar energy to generate air conditioning systems [18]. Photovoltaic collectors are used to feed the air conditioning system, and the benefit of using photovoltaic systems is their economy [19]. The compensation system between the solar energy that works to generate the air conditioning by PV panels contains four parts: a PV module, batteries, a charge controller, and the air conditioner [20]. Parking a car under the sun for a long time leads to an increase in the temperature inside the car and, thus, can cause a feeling of discomfort for the driver and the persons inside the vehicle within the first few seconds after entering the vehicle; therefore, the driver will inevitably turn on the air conditioning to a high level, which will overload the air conditioning system in the vehicle due to the increase in the thermal load on it and have an effect on the fuel consumption [21]. To improve the thermal comfort inside the vehicle's cabin, we must reduce the unwanted temperature increase that occurs when the vehicle is parked under the sun. To do this, it is important to ensure continuous air exchange between the inside and the outside of the vehicle's cabin without affecting the vehicle [21]. The feeling of discomfort that the driver feels when entering a vehicle that has been parked under the sun and that results from the high temperature inside the car can be reduced by having a ventilation system that provides ventilation inside the car and improves the environment of the car's cabin. Currently, some of the new luxury vehicles have a ventilation system that directly or indirectly depends on the fuel, which will lead to the production of emissions that have an effect on the environment and the consumption of energy. This study used a solar wing as the ventilation system's power supply and circulated the air by exchanging it between the inside and the outside of the car's cabin. This research was conducted in two main steps. In the first step, we established a module for the transfer of static thermal energy in the crew cabin based on the parameters of the ventilation pipe module. In the second step, we built a ventilation model for the outside circulation, then controlled the temperature inside of the cabin by determining the solar wing parameters and analyzing the interaction between the solar wing and the ventilator. The experimental results show that this system can reduce the temperature inside the cabin by up to $15{ }^{\circ} \mathrm{C}$ [22]. The removal of hot air from a vehicle typically requires the driver to perform some actions, such as opening a door and running the air conditioning to its maximum power. However, it will take time to reduce the temperature, and this will put an extra load on the engine that in turn will have an effect on the engine and also consume more fuel. There is another procedure that is used to slightly control increases in the temperature that involves opening windows and shading via curtains; however, this procedure is not very effective because, using this method, it is hard to remove the heat that is inside the vehicle and make the internal temperature close to the outside temperature [23]. A ventilation system can be used in a closed area, such as a vehicle's cabin, to exchange the air by allowing the hot air to be replaced by fresh air from outside the vehicle's cabin. Many studies have been conducted on ventilation systems for vehicles parked under the sun in the summer. This system prevents the temperature of the cabin from increasing while it is parked under the sun and uses solar energy to activate the ventilation system [24]. Table 1 presents a list of studies that have proposed systems to reduce the greenhouse effect in the cabins of cars parked under the blazing sun and the different methods the studies used to reduce the temperature inside the car. 
Table 1. Literature Review Summary.

\begin{tabular}{|c|c|c|c|c|}
\hline Year & Reference & Location & Proposed System & Main Result \\
\hline 2005 & {$[25,26]$} & USA & Cracked the window for 1.5 inch. & $\begin{array}{l}\text { Slightly opening the windows does not considerably } \\
\text { impede the heating process or reduce the maximum } \\
\text { temperature reached. }\end{array}$ \\
\hline 2006 & [27] & Morocco & \multirow{3}{*}{$\begin{array}{l}\text { Reflecting glazing. } \\
\text { Solar reflective glass. } \\
\text { Solar photovoltaic panel to power } \\
\text { the ventilator. }\end{array}$} & Temperature reduction is almost $7^{\circ} \mathrm{C}$. \\
\hline 2007 & {$[21]$} & USA & & Air temperature reduction by $12^{\circ} \mathrm{C}$. \\
\hline 2009 & [28] & Malaysia & & Temperature reduction is almost $7^{\circ} \mathrm{C}$. \\
\hline 2009 & [29] & USA & $\begin{array}{l}\text { Built a daily data set consisting of } \\
\text { maximum cabin temperature. }\end{array}$ & $\begin{array}{l}\text { The range of the maximum cabin temperatures, } \\
41-76^{\circ} \mathrm{C} \text {, that's depending on the weather conditions } \\
\text { and the time of year. }\end{array}$ \\
\hline 2011 & {$[30]$} & Malaysia & \multirow{3}{*}{$\begin{array}{l}\text { Portable car cooling system. } \\
\text { Solar energy powered ventilation } \\
\text { system. } \\
\text { Passive method in reducing } \\
\text { greenhouse effect by using } \\
\text { ventilators, sunshades and } \\
\text { window tints. }\end{array}$} & Temperature reduction is almost $25^{\circ} \mathrm{C}$. \\
\hline 2012 & [31] & Thailand & & Replace car cabin hot air by ambient cold fresh air. \\
\hline 2014 & [32] & Malaysia & & Average temperature reduction is almost $3.3^{\circ} \mathrm{C}$. \\
\hline 2014 & [33] & Romania & $\begin{array}{l}\text { Solar energy powered ventilation } \\
\text { system. }\end{array}$ & $\begin{array}{l}\text { Efficient ventilation was calculated at } 0.02 \mathrm{~m}^{3} / \mathrm{s} \text { air } \\
\text { flow. }\end{array}$ \\
\hline 2015 & [34] & Iraq & $\begin{array}{c}\text { Car cover with } 1 \mathrm{~cm} \text { cracked } \\
\text { windows. }\end{array}$ & $\begin{array}{c}\text { Car cabin compartment temperature reduced by } 70 \% \\
\text { comparing with base case. }\end{array}$ \\
\hline 2015 & [35] & Malaysia & $\begin{array}{l}\text { Sun shades in parallel with } \\
\text { various configuration of the } \\
\text { windows closed or opened. }\end{array}$ & Average temperature reduction is almost $26 \%$. \\
\hline 2015 & [36] & Malaysia & $\begin{array}{l}\text { Solar energy powered ventilation } \\
\text { system. }\end{array}$ & Average temperature reduction is around $15^{\circ} \mathrm{C}$. \\
\hline 2015 & [37] & Oman & $\begin{array}{l}\text { Solar energy powered ventilation } \\
\text { system. }\end{array}$ & Average temperature reduction is around $10^{\circ} \mathrm{C}$. \\
\hline 2015 & [22] & China & Ventilation system. & Maximum temperature reduction is around $15^{\circ} \mathrm{C}$. \\
\hline 2015 & [38] & China & $\begin{array}{l}\text { Original ventilator powered by } \\
\text { solar energy. } \\
\text { Thermoelectric cooling (TEC) }\end{array}$ & $\begin{array}{l}\text { The temperature inside the vehicle cabin higher than } \\
\text { the highest environmental temperature by } 5 \text { to } 10^{\circ} \mathrm{C} \text {. }\end{array}$ \\
\hline 2016 & [39] & UAE & $\begin{array}{l}\text { equipment fueled by solar energy } \\
\text { that will remove heat from the } \\
\text { vehicle cabin. }\end{array}$ & Average temperature reduction is $4^{\circ} \mathrm{C}$. \\
\hline 2017 & [40] & Korea & Ventilation system. & Thermal comfort improvement by $20 \%$. \\
\hline 2017 & [41] & Malaysia & $\begin{array}{l}\text { Solar energy powered ventilation } \\
\text { system. }\end{array}$ & Average temperature reduction is around $10^{\circ} \mathrm{C}$. \\
\hline 2017 & [42] & China & $\begin{array}{l}\text { Solar energy powered cooling } \\
\text { system }\end{array}$ & Average temperature reduction is around $4.2^{\circ} \mathrm{C}$. \\
\hline 2017 & [43] & China & $\begin{array}{c}\text { Solar energy powered cooling } \\
\text { system }\end{array}$ & Temperature drop of $30^{\circ} \mathrm{C}$ in the test field \\
\hline 2018 & {$[44]$} & Malaysia & $\begin{array}{l}\text { Solar energy powered ventilation } \\
\text { system. }\end{array}$ & Reduction in the inside temperature about $12 \%$ \\
\hline 2019 & [2] & China & $\begin{array}{l}\text { Solar energy powered cooling } \\
\text { system. }\end{array}$ & $\begin{array}{l}\text { When compared to a traditional automobile air } \\
\text { conditioning system, it performs similarly. }\end{array}$ \\
\hline 2020 & [4] & China & $\begin{array}{l}\text { Solar energy powered cooling } \\
\text { system. }\end{array}$ & Average temperature reduction is $27.45^{\circ} \mathrm{C}$. \\
\hline
\end{tabular}

In general, this study aims to reduce the greenhouse effect in car cabins parked under the blazing sun on hot days. This problem has many effects on many domains, such as that that many children have died around the world because of this phenomenon, that energy is wasted in consuming more fossil fuel to cool the car cabin, and effects on the environment by increasing the emissions and effects on the car interior parts. Therefore, this study will propose a ventilation system powered by solar energy, test it, and record the results before showing the performance and efficiency of the proposed system. Our study is focused on two goals: the first is to know how much the temperature rises, on 
average, in a car cabin comparing to the ambient temperature due to the greenhouse effect in Jordan, and this will provide knowledge about the greenhouse effect in countries with a similar climate. The second is how to overcome the rising temperature, we proposed the solar ventilation system with some modifications such as increasing the ventilation fan flow rate and circulating the hot air by the use two ventilation fans; one as a supply air fan and the other one to return air. The main objectives of the proposed system are as follows:

- To demonstrate that the vehicle's environmental state has clearly improved and that a solar-powered ventilation system is practical and feasible;

- Design and fabricate the proposed ventilation system and compare the results with and without using this system;

- Improve the environment in the vehicle by using this system as an exhaust gas system that is provided with a filter.

\section{Methodology and Experimental Design}

The methodology of this study is presented through the method flow chart in Figure 1. This flow chart includes the outlines and the techniques which are used in this research, starting with the data gathering, then moving on to designing, fabricating a prototype, experimental work results, recording the results and findings, and the conclusion and recommendations.

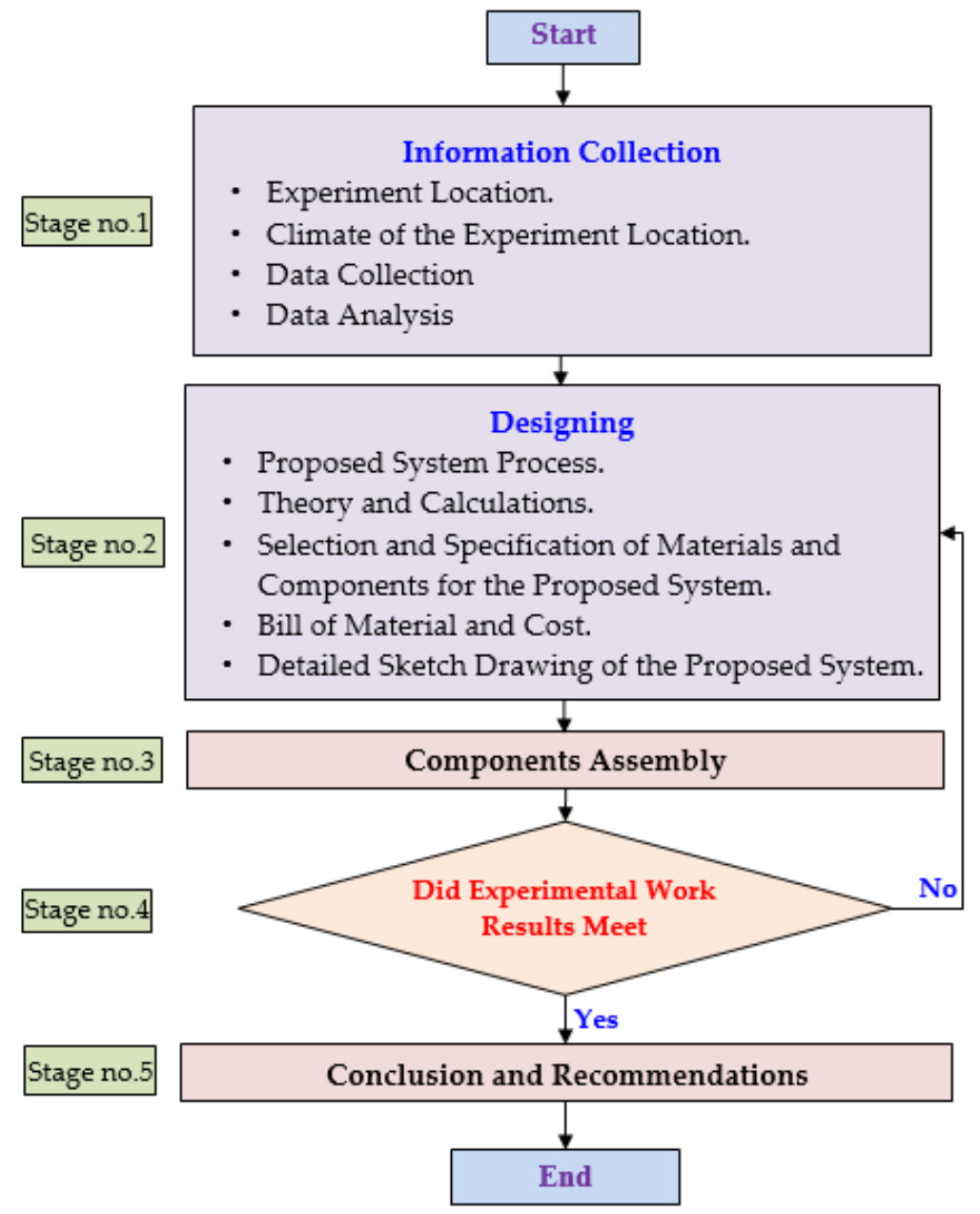

Figure 1. Method flow chart. 


\subsection{Experiment Location}

The location of the model test is Ma'an, which is located in the south of Jordan, $218 \mathrm{~km}$ southwest of the capital Amman. It is located at the latitude of $30^{\circ} \mathrm{N}$ and the longitude $35^{\circ}$ E, as shown in Figure 2 [45].

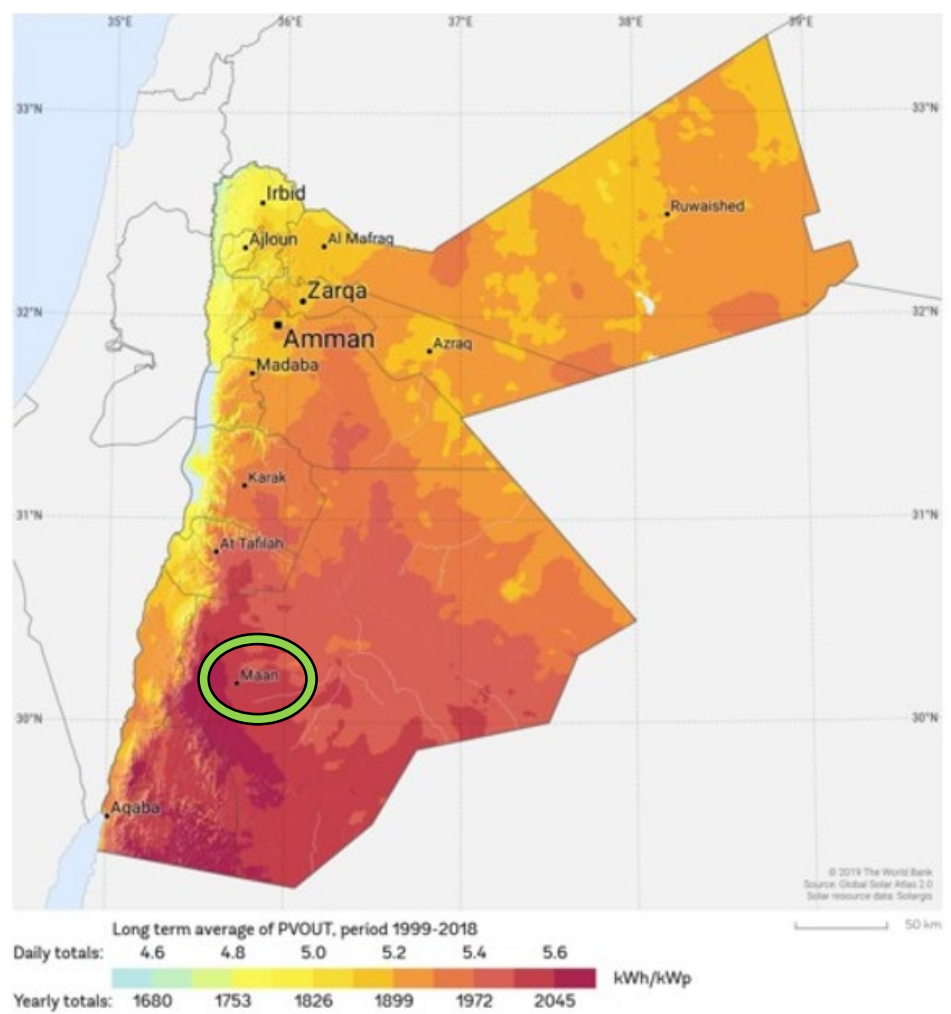

Figure 2. Location of the studied area.

\subsection{Climate of $M a^{\prime}$ an City}

Ma'an city weather is characterized by heat and dryness in the summer, the data give us the solar radiation and climatic data give us the average day and night temperature, monthly hours of sunshine, average humidity, and monthly averages direct normal irradiation in Ma'an city, shown in Figures 3 and 4. Below, Figure 3 presents the average day and night temperature in Ma'an city as well as the average humidity in Ma'an city.

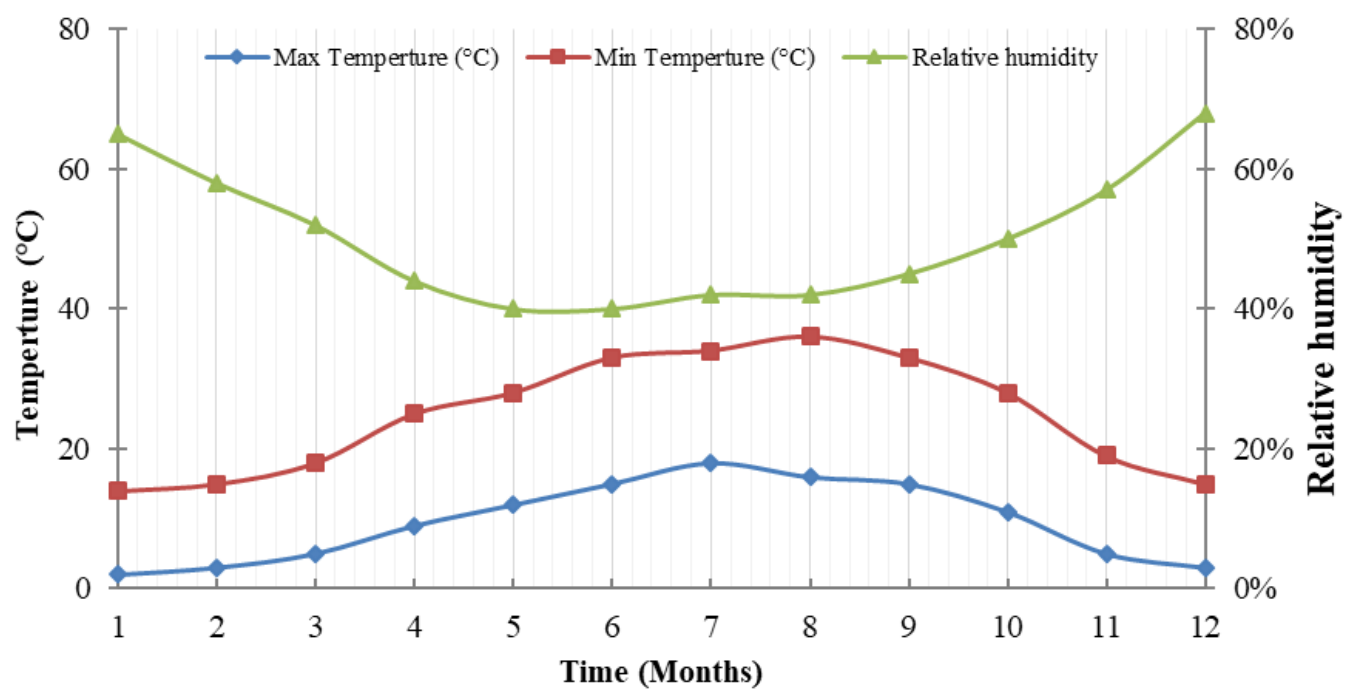

Figure 3. Average day and night temperature and average humidity [46]. 


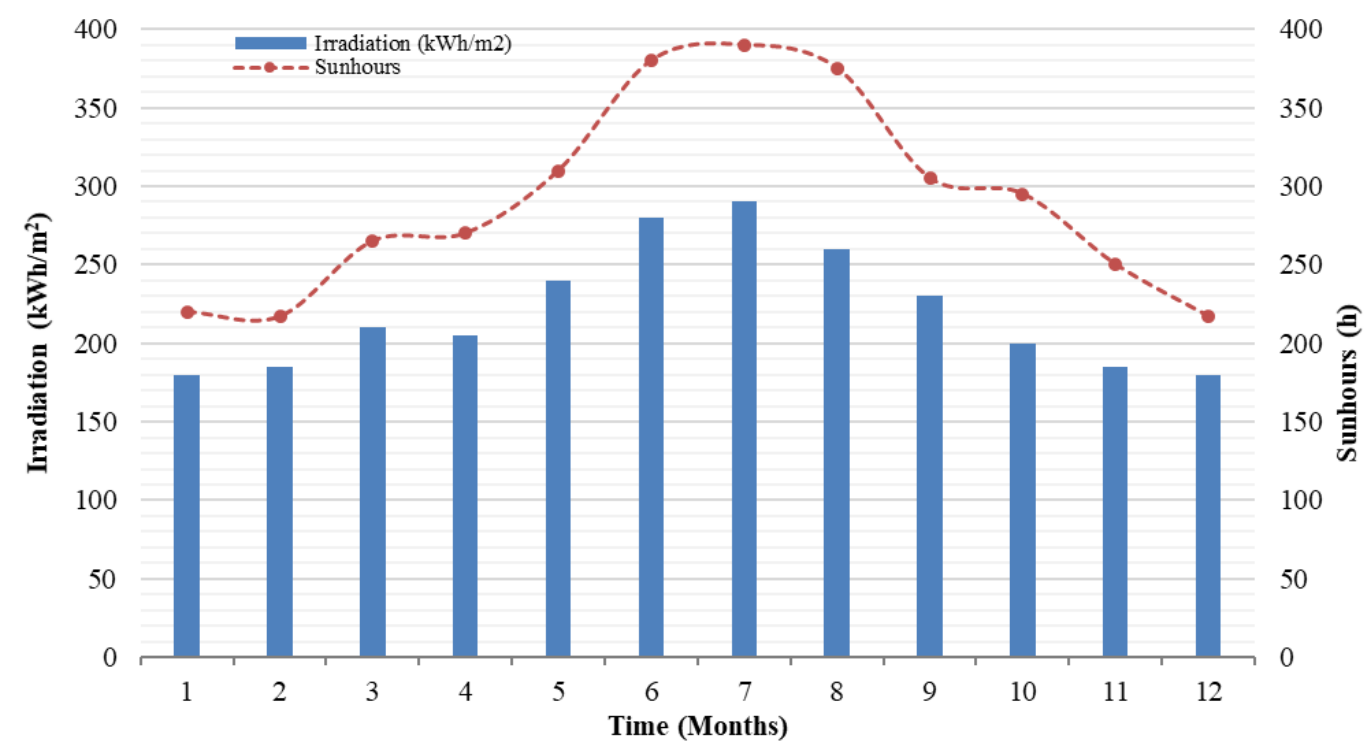

Figure 4. Monthly averages of direct normal irradiation and monthly hours of sunshine in Ma'an city [26].

Also, Figure 4 presents the monthly averages of direct normal irradiation and monthly hours of sunshine in Ma'an city.

\subsection{Data Collection}

Data collections depend on collecting realistic information about the temperature in a closed vehicle which is parked under the sun for several hours (Figure 5). This process was done by using a thermometer, which measures the temperature of the vehicle from the inside and outside, and knows the difference in temperature between them; this process took place between 10:00 a.m. and 4:00 p.m.

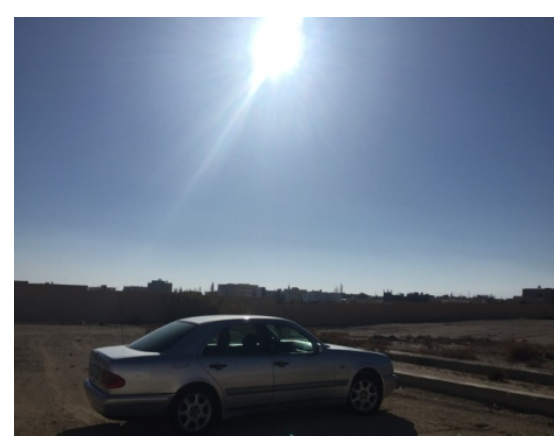

(a)

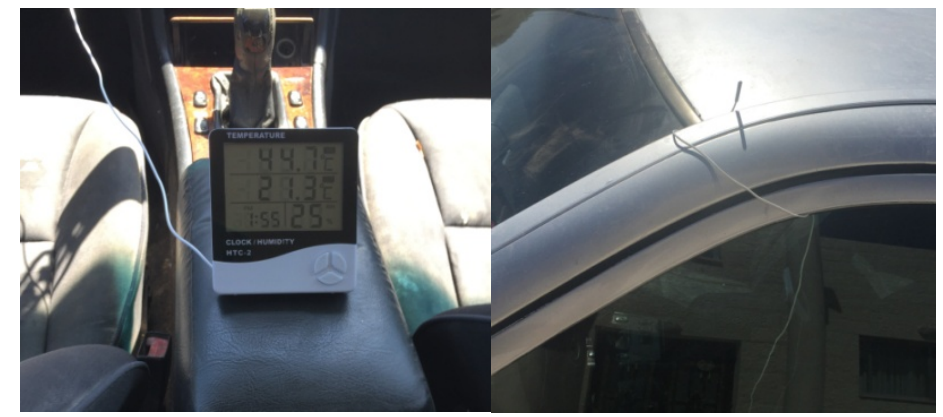

(b)

Figure 5. (a) Car parked under blazing sun for data collection and (b) thermometer for the collection of in and outside cabin temperature.

\subsection{Data Analysis}

The data collection showed a large difference between the internal and external car temperature, as shown in Table 2. The temperature difference reached about $20^{\circ} \mathrm{C}$; therefore, we require a system to reduce the interior temperature to reach as much as ambient temperature as possible. In this method, a ventilation system is used to reduce the car cabin temperature. 
Table 2. Car cabin temperature and ambient temperature.

\begin{tabular}{cccc}
\hline Time & $\begin{array}{c}\text { Ambient } \\
\text { Temperature }\left({ }^{\circ} \mathbf{C}\right)\end{array}$ & $\begin{array}{c}\text { Car Cabin } \\
\text { Temperature }\left({ }^{\circ} \mathbf{C}\right)\end{array}$ & $\begin{array}{c}\text { Temperature } \\
\text { Difference }\left({ }^{\circ} \mathbf{C}\right)\end{array}$ \\
\hline 10:00 a.m. & 14.9 & 31.3 & 16.4 \\
10:30 a.m. & 17.5 & 33 & 15.5 \\
11:00 a.m. & 18.1 & 35.5 & 17.4 \\
11:30 a.m. & 18.4 & 37.6 & 19.2 \\
12:00 p.m. & 20 & 40.5 & 20.5 \\
12:30 p.m. & 20.5 & 42.1 & 21.6 \\
01:00 p.m. & 20.9 & 43.5 & 22.6 \\
01:30 p.m. & 21.1 & 44.1 & 23 \\
02:00 p.m. & 21.3 & 44.7 & 23.4 \\
02:30 p.m. & 21.6 & 44.6 & 23 \\
03:00 p.m. & 22 & 44.6 & 22.6 \\
03:30 p.m. & 21.8 & 43.3 & 21.5 \\
04:00 p.m. & 21.6 & 43.1 & 21.5 \\
\hline
\end{tabular}

The most important stage is designing. All the details of the design features of the ventilation system powered by solar energy were created, and there were six main tasks in this stage which are as follows.

\subsubsection{Process Flow of the Proposed System}

The process flow of the proposed system as mentioned in Figure 6; in this system, the photovoltaic panel converts the solar energy to electrical energy to operate the ventilation fan or to charge the battery, and the energy-charged in the battery is used once the energy from the photovoltaic panel not sufficient to power the fan. The function of this system is to vent the hot air out to the surroundings, and this system is controlled by thermostat by entering the set point temperature so that, once the car cabin temperature is more than this set point, the system turns on. The fan and the system turn off when the car cabin temperature is below the set temperature.

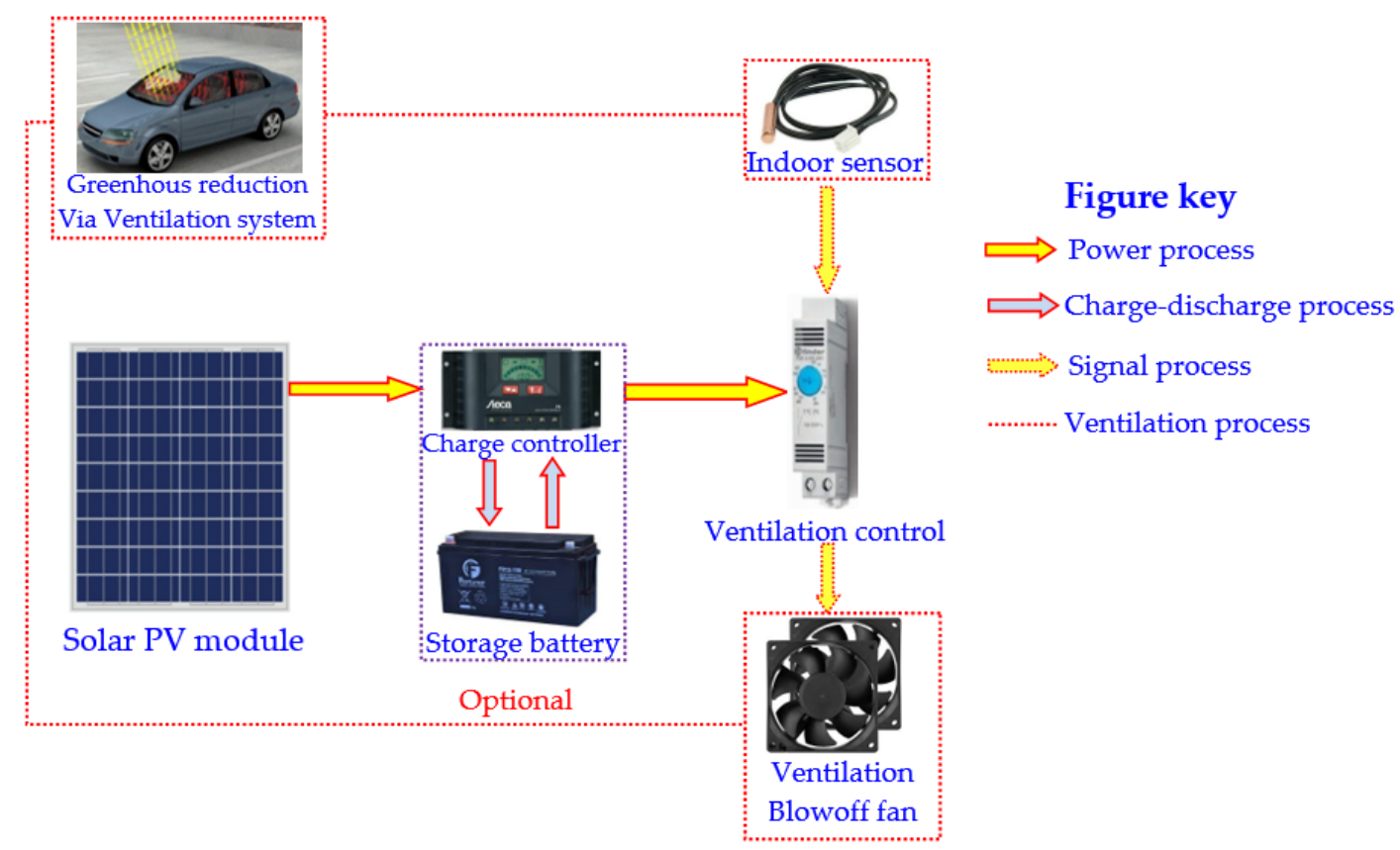

Figure 6. Process flow of solar PV panel powered ventilation fan in car cabin. 


\subsubsection{Theory and Calculations}

This section determines the theoretical calculation of the system which contains the calculation for the system components which are the ventilation fan, photovoltaic panels, charge controller, and the control system.

\section{Ventilation Fan Calculations}

The calculation and selection of the ventilation fan is based on many conditions. In the proposed study, the ventilation fan calculation has five steps which are as follow.

- The first step is to calculate the car cabin volume by using Equation (1) after measuring the car cabin dimensions;

- The second step is to calculate the heat quantity in the car cabin parked under the blazing sun by using Equation (2);

- The third step is to calculate the power required by the ventilation fan by using Equation (3);

- The fourth step is to calculate the ventilation fan current for the proposed system using Equation (4);

- The fifth step is to calculate the fan flow rate based on the air change per hour using Equation (5).

The first step is to calculate the car cabin volume by using Equation (1). The car cabin volume is measured by neglecting the seats; the volume of the car means the volume of the hot air in the car cabin.

$$
V=I \times W \times H
$$

where $V$ is the interior volume of the vehicle $\left(\mathrm{m}^{3}\right), I$ is the interior length of the vehicle $(\mathrm{m})$, $W$ is the interior width of the vehicle $(\mathrm{m})$, and $H$ is the interior height of vehicle $(\mathrm{m})$.

Figure 7a,b, below, show the vehicle cabin dimensions to be measured for the volume of hot air in the vehicle cabin in the proposed system. The volume of the vehicle cabin is considered to be that of a box, with dimensions as given in Figure $7 \mathrm{~b}$. Using this method, the volume will be slightly more, and this is an advantage as a factor of safety of the design.

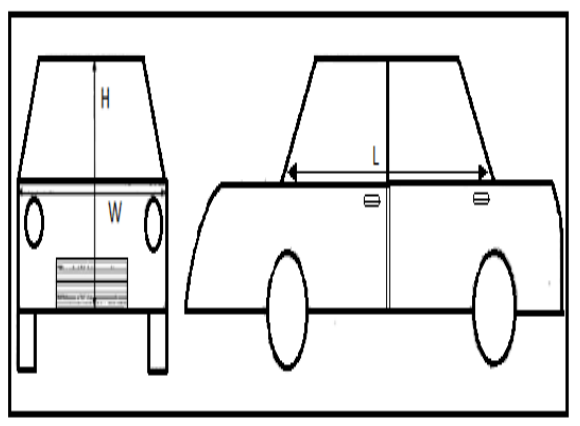

(a)

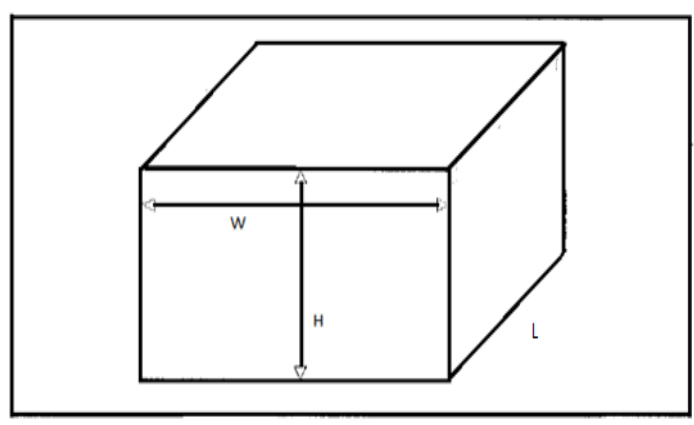

(b)

Figure 7. Car cabin (a) assembly and (b) dimension.

The second step is to calculate the amount of heat inside the car cabin through Equation (2), which shows the formula to calculate heat quantity based on the car cabin volume and the difference in temperature between the car cabin and the ambient temperature. This difference in temperature is clearly shown in the Table 2, and, therefore, the heat quantity equation leads us to find the proposed ventilation fan power required, which can be calculated as:

$$
Q_{\mathrm{h}}=\rho_{\mathrm{a}} \times V \times C a \times\left(T_{1}-T_{2}\right)
$$

where $Q_{\mathrm{h}}$ : car cabin heat quantity $(\mathrm{kJ}), \rho_{\mathrm{a}}$ : air density $\left(\mathrm{kg} / \mathrm{m}^{3}\right), V$ : car volume $\left(\mathrm{m}^{3}\right), C a$ : air specific heat $\left(\mathrm{kJ} / \mathrm{kg} \cdot{ }^{\circ} \mathrm{C}\right)$, and $\left(T_{1}-T_{2}\right)$ : temperature difference $\left({ }^{\circ} \mathrm{C}\right)$.

Equation (2) shows that the heat quantity is proportional of the volume of the car cabin, meaning that a large car cabin volume increases the amount of heat quantity at the 
same temperature, and, therefore, the volume of the car cabin effects the proposed system components design, capacity, and dimensions.

The third step is to calculate the ventilation fan power, which is based on the heat quantity, is shown in the Equation (3):

$$
P=Q_{\mathrm{h}} / t
$$

where $P$ : ventilation fan power $(\mathrm{W}), Q_{\mathrm{h}}$ : car cabin heat quantity $(\mathrm{kJ})$, and $t$ : time (s).

The fourth step to calculate the ventilation fan current from Equation (4) is as follows.

$$
I=P / V C
$$

where I: current required (A), $P$ : ventilation fan power $(\mathrm{W})$, and $V c$ : voltage that need to be supplied (V).

The fifth step is to calculate the ventilation fan flow rate based on the air change per hour required, shown as follows.

$$
Q=A C P H \times V
$$

where $Q$ : air flow rate $\left(\mathrm{m}^{3} / \mathrm{h}\right), A C P H$ : air change per hour $\left(\mathrm{h}^{-1}\right)$, and $V$ : car cabin volume $\left(\mathrm{m}^{3}\right)$.

For the proposed system, we applied the previous four steps to the car used in the experiment stage, which was a Mercedes E200.

\section{Photovoltaic Panels Calculations}

The capacity of the solar photovoltaic is based on the power of the electrical device, which is the ventilation fan in the proposed system.

To determine the capacity of the solar panel required, the first step was to find the average watt hour per day (Wh/day). From the ventilation fan calculation, we found that the power was $40 \mathrm{~W}$ and the average running hours per day was $n$ (which is equal to $6 \mathrm{~h}$ per day). Therefore, the average energy produced $E_{\text {ave, }}(\mathrm{Wh} /$ day), calculated as Equation (6).

$$
E_{\text {ave }}=\text { Produced power }(W) \times n(h / \text { day })
$$

The second step determines the rated peak power of the PV array from Equation (7), and this equation is used to determine the power for the solar panel that covers the demands of the proposed ventilation system.

$$
P_{\mathrm{PV}}=E_{\mathrm{D}} / S P \times \eta
$$

where $P_{\mathrm{PV}}$ : rated power of PV system $(\mathrm{kWp}), E_{\mathrm{D}}$ : average daily amount of electricity $(\mathrm{kWh} /$ day), SP: number of sun peak hours/day (h/day), and $\eta$ : overall system efficiency $(\%)$.

\section{Solar Storage Battery Calculations}

The battery (option) is used to cover the hot cloudy days or dusty days and is also suitable to a new technology car (hybrid or pure electricity cars), when no electricity is needed for the ventilation system. The battery capacity of the proposed system is based on Equation (8). This equation is used to determine the capacity of the battery that is used to store the solar radiation once the system is not on, and it is also used to power the system when the solar radiation not sufficient

$$
C=N \times E_{D} / D \times \eta_{\text {inv }}
$$

where $C$ : battery capacity $(\mathrm{kWh}), N$ : number of days of storage, $D$ : allowable battery depth-discharge, and $\eta_{\text {inv }}$ inverter efficiency (\%). 


\section{Charge Controller Calculation}

The charge controller (optional if the battery is used) is used to prevent the solar battery from overcharging and over-discharging. It is used to regulate the energy flow into batteries. The charge controller transfers the energy from the photovoltaic panels to the batteries as a DC system coupled from the wattage of the solar panel and the voltage of the battery. The proposed system requires a charge controller that can support at least 3.3 Amps.

\section{Ventilation Control System}

The control system for the proposed system is a thermostat to control the temperature inside the car cabin by entering the set point temperature and, once the temperature inside the car cabin matches with the set temperature, the proposed ventilation system turns on and, once the temperature is reduced to below the set point temperature, the system turns off.

\subsubsection{Proposed System Material Quantity and Cost}

This section gives a list of components that make up our system and its cost; a material quantity and cost for the proposed system would include all the main parts and sub parts. Below, Table 3 shows the main parts quantity and cost.

Table 3. Proposed System Material Quantity and Cost.

\begin{tabular}{ccccc}
\hline Item & Qty. & Unit & Unit Cost (\$) & Total Cost (\$) \\
\hline Ventilation Fan & 2 & Pcs & 10 & 20 \\
Solar Photovoltaic Panels & 4 & Pcs & 15 & 60 \\
Storage Battery & 1 & Pcs & 70 & 70 \\
Charge Controller & 1 & Pcs & 25 & 25 \\
Ventilation Control & 1 & Pcs & 15 & 15 \\
\hline & & & Total (\$) & 190 \\
\hline
\end{tabular}

\subsubsection{Selection and Specification of Proposed System}

This section and Table 4 present the system components selection and specification for the major components which are ventilation fan, solar photovoltaic panels, battery, charge controller, and control system.

Table 4. Selection and Specification of the Proposed System.

\begin{tabular}{cc}
\hline Item & Description \\
\hline 1-Ventilation Fan Specification & \\
\hline Brand & DELTA \\
Model & PFC0612DE-F00 \\
Rated Voltage & 12 VDC \\
Operation Voltage & $10.8-13.2$ VDC \\
Input Current & 1.40 (Max. 1.68) A \\
Input Power & 16.8 (Max. 20.16) W \\
Max Air Flow & 67.85 CFM \\
Min Air Flow & 61.06 CFM \\
Life Expectance & with 15-65\%RH \\
Rotation & Clockwise View from Name Plate Side \\
\hline 2-Photovoltaic Panels Specification & SONALI \\
\hline Brand & SSF-MF-20-36-12V \\
Model & Polycrystalline \\
Type &
\end{tabular}


Table 4. Cont.

\begin{tabular}{|c|c|}
\hline Item & Description \\
\hline Maximum Power (Pmp) & $20 \mathrm{Wp}$ \\
\hline Open Circuit Voltage $\left(V_{\mathrm{oc}}\right)$ & $21.5 \mathrm{~V}$ \\
\hline Short Circuit Current $\left(I_{\mathrm{sc}}\right)$ & $1.21 \mathrm{~A}$ \\
\hline Voltage at Maximum Power $\left(V_{\mathrm{mp}}\right)$ & $17.4 \mathrm{~V}$ \\
\hline Current at Maximum Power $\left(I_{\mathrm{mp}}\right)$ & $1.15 \mathrm{~A}$ \\
\hline Module Dimension & $480 \times 360 \times 25 \mathrm{~mm}$ \\
\hline Module Weight & $2.0 \mathrm{~kg}$ \\
\hline \multicolumn{2}{|l|}{ 3-Storage Battery Specification } \\
\hline Brand & Excellence Solar \\
\hline Model & FP20012015 \\
\hline Weight & $12 \mathrm{~kg}$ \\
\hline Voltage & $12 \mathrm{~V}$ \\
\hline Capacity (Ampere Hour) & $40 \mathrm{AH}$ \\
\hline Max. Initial Current & Less than $12 \mathrm{~A}$ \\
\hline Standby use & $13.50-13.80 \mathrm{~V}$ \\
\hline Cyclic & $14.50-14.90 \mathrm{~V}$ \\
\hline \multicolumn{2}{|l|}{ 4-Charge Controller Specification } \\
\hline Brand & STECA \\
\hline Model & PR 1010 \\
\hline Weight & $0.4 \mathrm{~kg}$ \\
\hline Dimensions & $187 \times 96 \times 44 \mathrm{~mm}$ \\
\hline Max input voltage & $<47 \mathrm{~V}$ \\
\hline Max output current & $10 \mathrm{~A}$ \\
\hline Supported Battery Voltage & $12 / 24 \mathrm{~V}$ \\
\hline \multicolumn{2}{|l|}{ 5-Ventilation Control Specification } \\
\hline Brand & Finder \\
\hline Model & 7 T.81-thermostat \\
\hline Setting range (ventilation) ${ }^{\circ} \mathrm{C}$ & $+0 \ldots+60$ \\
\hline Switch temperature differential $\mathrm{K}$ & $7 \pm 4$ \\
\hline Ambient temperature range & $-45 \ldots+80$ \\
\hline Contact configuration & $1 \mathrm{NO}$ \\
\hline
\end{tabular}

\subsubsection{Detailed Design Sketch of the Proposed System}

Figure 8, below, shows the detailed design sketch of the proposed system, Figure 8a shows the connection between the proposed system main parts, and Figure 8b shows the location of the main parts in the vehicle.

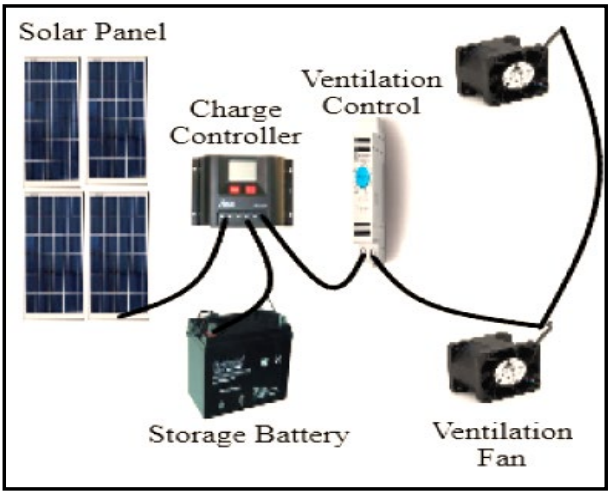

(a)

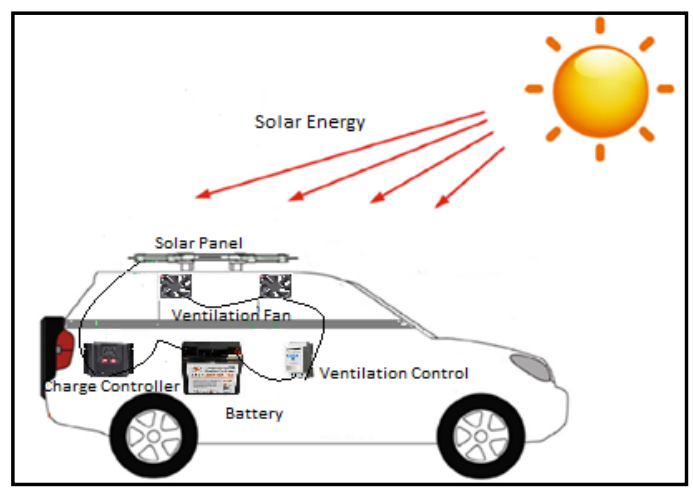

(b)

Figure 8. $(\mathbf{a}, \mathbf{b})$ detailed connection photo of the proposed system. 


\subsubsection{System Fabrication}

The vehicle ventilation system prototype was built with all of the technical design, features, and requirements described in the previous stage in mind.

The fabrication stage process is composed of two steps for the proposed system. The first step is to make the connection in the laboratory and check the system operation as mentioned in Figure 9, and the second step is to fix the solar panel to the car roof, fix the ventilation fan in the car window, and connect the system components together, which are photovoltaic charge controller, storage battery, ventilation control, and ventilation fan, as mentioned in Figure 10a,b.

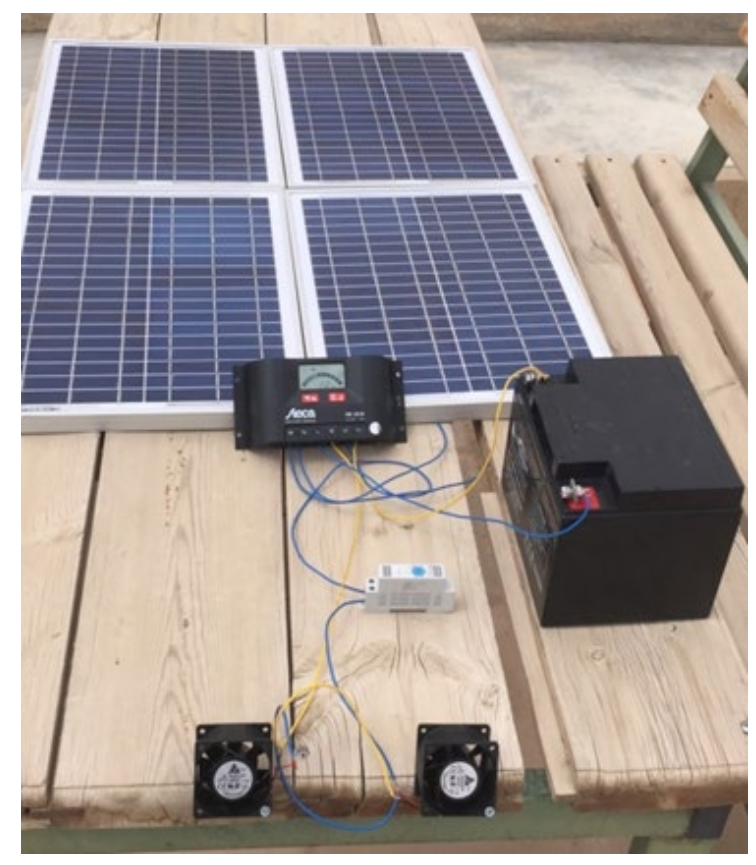

Figure 9. Prototype connection in the laboratory.

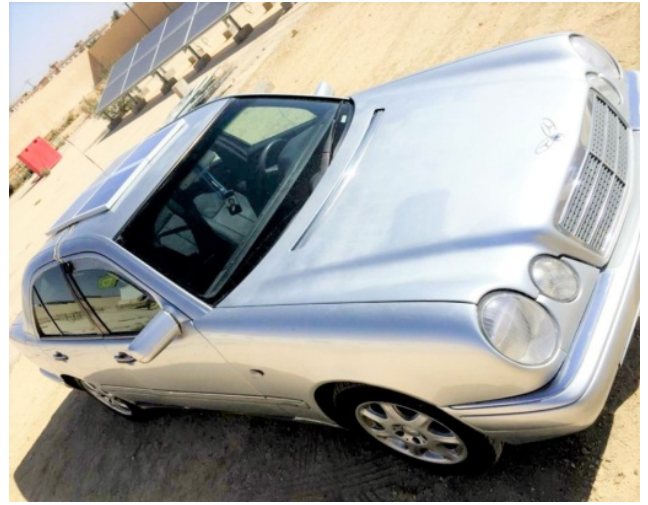

(a)

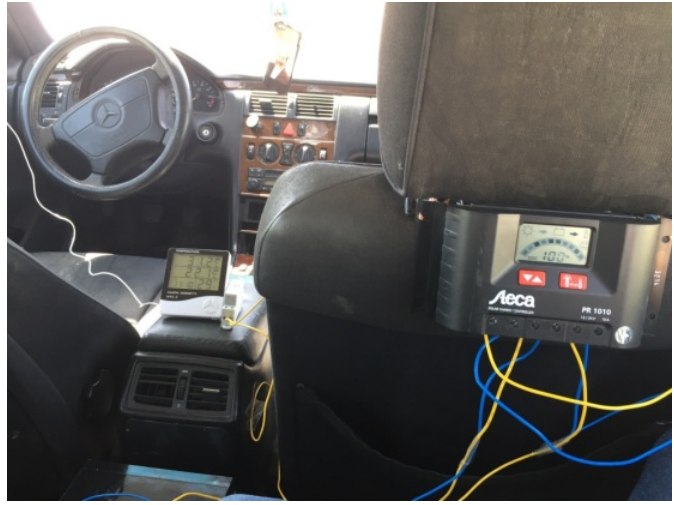

(b)

Figure 10. Proposed system final connection. (a) Front view and (b) inside car cabin.

\section{Results and Discussions}

We tested the proposed prototype to check if it has achieved the project objective or not, and we also tested the product validation used to check the prototype at actual condition. The test was conducted by using a Mercedes Benz E200 with the proposed system.

The product validation procedure has two steps:

1. First step (car without proposed system) 
- Park the car in an open space on a hot day;

- Measure the temperature in the car and ambient temperature starting from 10:00 a.m. to 4:00 p.m. without installing the proposed system;

- Record the difference in the temperature between the car cabin and the ambient temperature.

2. Second step (car with proposed system)

- Park the car in an open space on a hot day;

- Install the proposed system;

- Measure the temperature in the car and ambient temperature starting from 10:00 a.m. to 4:00 p.m.;

- Conclude the effectiveness of the design based on the results.

\subsection{First Step (Car Cabin and Ambient Temperature without Proposed System)}

Figure 11, below, presents the temperature difference between the car cabin and the ambient temperature without the proposed system on several days (29 March 2021-3 May 2021). These results have shown the greenhouse effect in the car cabin and how it increases the temperature inside the car over time; from the below figure we conclude the following:

- The maximum car cabin temperature during the experiment tests was $53.9^{\circ} \mathrm{C}$ on 19 April 2021 where the ambient temperature was $34.1^{\circ} \mathrm{C}$ at 1:30 p.m.;

- The maximum temperature difference between the car cabin and ambient temperature was $23.4^{\circ} \mathrm{C}$, occurring on 29 March 2021 at 2:00 p.m.;

- The maximum daily average temperature difference between the car cabin and ambient temperature was $20.6^{\circ} \mathrm{C}$, occurring on 29 March 2021;

- The minimum car cabin temperature during the experiment was $30.1^{\circ} \mathrm{C}$ on 11 April 2021, where the ambient temperature was $19.2^{\circ} \mathrm{C}$ at 10:00 a.m.;

- The minimum temperature difference between the car cabin and ambient temperature was $10.1^{\circ} \mathrm{C}$ on 11 April 2021 at 10:00 a.m.

- The minimum average temperature difference between the car cabin and ambient temperature was $17.6^{\circ} \mathrm{C}$, occurring on 29 April 2021.

- The average temperature difference between the car cabin and ambient temperature during the experimental tests was $18.7^{\circ} \mathrm{C}$.

Excessive automobile cabin temperature places a large thermal strain on the vehicle's air conditioning system, increasing fuel consumption and emissions. In addition, as seen in the graph below, the temperature profile within the vehicle cabin, it goes without saying that this is extremely dangerous to humans, and the temperature is much over the human thermal comfort zone. 


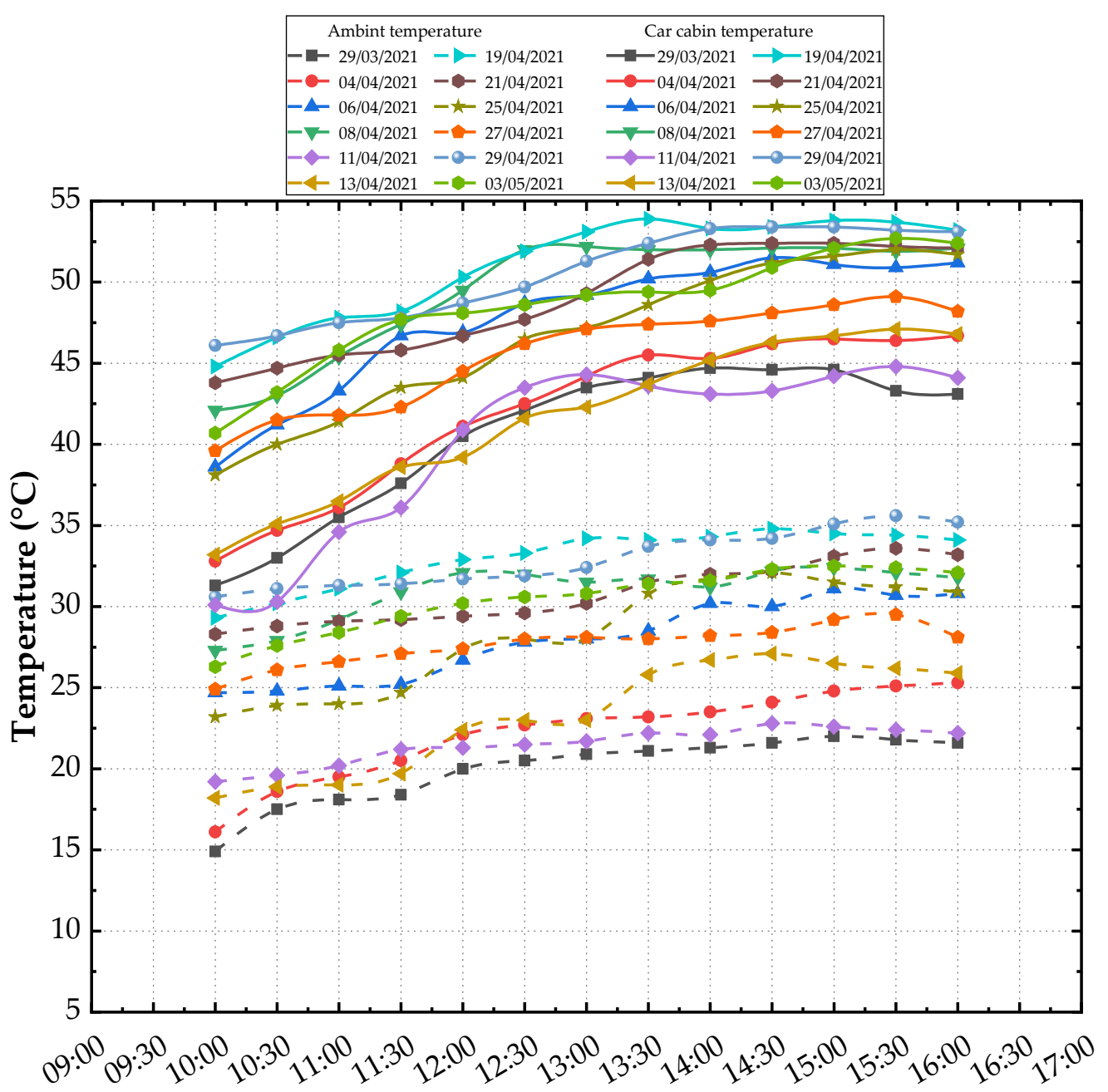

Time (h)

Figure 11. Vehicle cabin and ambient temperature without proposed system.

\subsection{Step Two (Vehicle Cabin and Atmosphere Temperature with Proposed System)}

Figure 12 presents the temperature difference between the vehicle cabin and atmosphere temperature with the proposed solar ventilation system over the course of several days (30 March 2021-4 May 2021), and, from the below figure, we conclude the following:

- The maximum vehicle cabin temperature during the experiment was $45.4{ }^{\circ} \mathrm{C}$ on 2 May 2021, where the ambient temperature was $37.7^{\circ} \mathrm{C}$ at 2:30 p.m.;

- The maximum temperature differential between the vehicle cabin and atmosphere temperature was $9.6^{\circ} \mathrm{C}$, occurring on 22 April 2021 at 2:30 p.m.;

- The maximum daily average temperature differential between the vehicle cabin and atmosphere temperature was $7.2^{\circ} \mathrm{C}$, occurring on 22 April 2021;

- The minimum vehicle cabin temperature during the experiment was $23^{\circ} \mathrm{C}$ on 30 March 2021, where the ambient temperature was $18.2{ }^{\circ} \mathrm{C}$ at 10:00 a.m.;

- The minimum temperature differential between the vehicle cabin and atmosphere temperature was $3.6^{\circ} \mathrm{C}$, occurring on 20 April 2021 at 10:00 a.m.;

- The minimum average temperature differential between the vehicle cabin and atmosphere temperature was $6.2^{\circ} \mathrm{C}$, occurring on 28 April 2021.

- The average temperature differential between the vehicle cabin and atmosphere temperature during the experimental tests was $6.7^{\circ} \mathrm{C}$. 


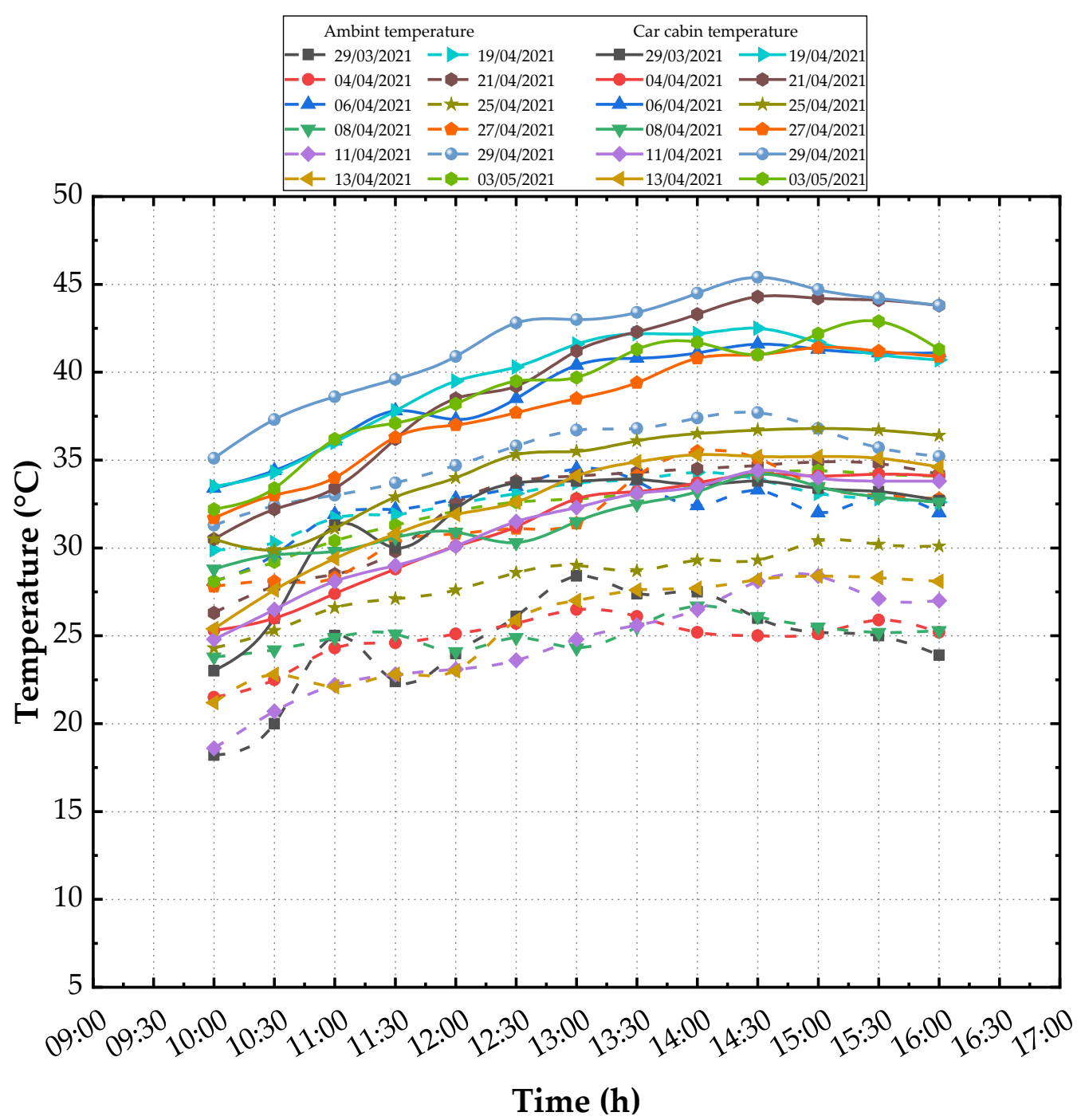

Figure 12. Car cabin and ambient temperature with proposed system.

These results have shown the reduction in the temperature difference between the car cabin and ambient temperature due to the used solar ventilator. This clearly reduces the heat burden on the car AC, making it more pleasant for drivers and passengers to enter the parked vehicle.

\subsection{Analysis of Results}

Several experiments or tests were conducted in order to investigate the performance of the proposed system; the results were separated into two groups: data collection without and with the proposed system.

Figures 11 and 12 plot the average temperature against time for both the planned system and without it. The temperature inside the automobile rose from 10 a.m. to 4 p.m., depending on the amount of sunshine exposure. The test was carried out across multiple days to avoid a lack of precision in the data collection.

On a sunny day, the temperature inside the cabin of the car started to rise gradually at around $10.00 \mathrm{a} . \mathrm{m}$. and reached its maximum at around 1.00 p.m. to 3.00 p.m., then again started to decrease as time elapsed. The highest average temperature inside the car during peak time was observed between 2.00 p.m. to 3:00 p.m., as per Table 5, which presents the experimental work results for the car cabin temperature with and without the solar ventilation system. Table 5 shows the maximum car cabin temperature during the experiment tests, the maximum temperature difference between car cabin and ambient 
temperature, the maximum daily average temperature difference between the car cabin and ambient temperature, the minimum car cabin temperature during the experiment, the minimum temperature difference between the car cabin and ambient temperature, the minimum average temperature difference between the car cabin and ambient temperature, and the average temperature difference between the car cabin and ambient temperature during the experimental tests. Hence, the heat gain in the car was reduced after the implementation of the ventilation system.

The proposed system has shown reduction in the temperature, this reduction by air circulation inside the car cabin, with the air flow for the proposed system being about $120 \mathrm{ft}^{3} / \mathrm{min}$. In the proposed system there are two ventilation fans, one supplies air and the other returns the cold air entered through the supply fan and the car cabin hot air vents so the heat does not stay longer inside the car cabin and the temperature increasing rate is less. The faster the air changes between the environments, the stronger the cooling effect would be achieved inside the car.

If a slight decrease in energy consumption can be applied to numerous automobiles, the energy consumed to air condition them has a considerable impact on vehicle fuel efficiency and exhaust emissions. The impact on national fuel usage might be enormous, and this is also an extra incentive to minimize the size of the air conditioning system. To lower the amount of gasoline consumed for climate control, the compressor's power draw from the engine must be reduced and, for a smaller AC (air conditioning) compressor, the weight is lower. The usage of air conditioning $(\mathrm{AC})$ in automobiles has been projected to increase carbon monoxide (CO) emissions by $0.99 \mathrm{~g} \mathrm{~km}^{-1}(71 \%)$ and nitrogen oxide (NOx) emissions by $0.12 \mathrm{~g} \mathrm{~km}^{-1}(81 \%)$, while reducing fuel economy by $2.0 \mathrm{~km} / \mathrm{L}(4.6 \mathrm{mpg})$ (22 percent). Generally, it was found that, for every $1{ }^{\circ} \mathrm{C}$ drop in automobile cabin temperature, $\mathrm{AC}$ compressor power may be reduced by around 4.1 percent [47]. The suggested study lowers the temperature in automobile cabins by $12{ }^{\circ} \mathrm{C}$. Therefore, the AC compressor power may be lowered by around $49 \%$, resulting in fuel savings (increasing about $1 \mathrm{~km} / \mathrm{L}$ ) and emissions reduction that are about half of what they are now.

Table 5. Experimental works results.

\begin{tabular}{ccc}
\hline Description & $\begin{array}{c}\text { Without Solar Ventilation } \\
\text { System Temperature }\left({ }^{\circ} \mathrm{C}\right)\end{array}$ & $\begin{array}{c}\text { With Solar Ventilation System } \\
\text { Temperature }\left({ }^{\circ} \mathrm{C}\right)\end{array}$ \\
\hline $\begin{array}{c}\text { The maximum car cabin temperature during the } \\
\text { experiment tests }\end{array}$ & $53.9^{\circ} \mathrm{C}$ & $45.4^{\circ} \mathrm{C}$ \\
$\begin{array}{l}\text { The maximum temperature difference between car cabin } \\
\text { and ambient temperature }\end{array}$ & $23.4^{\circ} \mathrm{C}$ & $9.6^{\circ} \mathrm{C}$ \\
$\begin{array}{c}\text { The maximum daily average temperature difference } \\
\text { between car cabin and ambient temperature } \\
\text { The minimum car cabin temperature during the } \\
\text { experiment }\end{array}$ & $20.6^{\circ} \mathrm{C}$ & $7.2^{\circ}$ \\
$\begin{array}{l}\text { The minimum temperature difference between car cabin } \\
\text { and ambient temperature }\end{array}$ & $30.1^{\circ} \mathrm{C}$ & $18.2^{\circ} \mathrm{C}$ \\
$\begin{array}{l}\text { The minimum average temperature difference between } \\
\text { car cabin and ambient temperature }\end{array}$ & $10.1^{\circ} \mathrm{C}$ & $3.6^{\circ} \mathrm{C}$ \\
$\begin{array}{l}\text { The average temperature difference between car cabin } \\
\text { and ambient temperature during the experimental tests }\end{array}$ & $17.6^{\circ} \mathrm{C}$ & $6.2^{\circ} \mathrm{C}$ \\
\hline
\end{tabular}

Figure 13 presents the experimental work results for the vehicle cabin temperature with and without the solar ventilation system and shows the maximum vehicle cabin temperature during the experiment tests, the maximum difference in temperature between the vehicle cabin and atmospheric temperature, the maximum daily average temperature difference between the vehicle cabin and atmospheric temperature, the minimum car cabin temperature during the experiment, the minimum temperature difference between the vehicle cabin and atmospheric temperature, the minimum average temperature difference 
between the vehicle cabin and atmospheric and the average temperature, and the difference between the vehicle cabin and atmospheric temperature during the experimental tests.

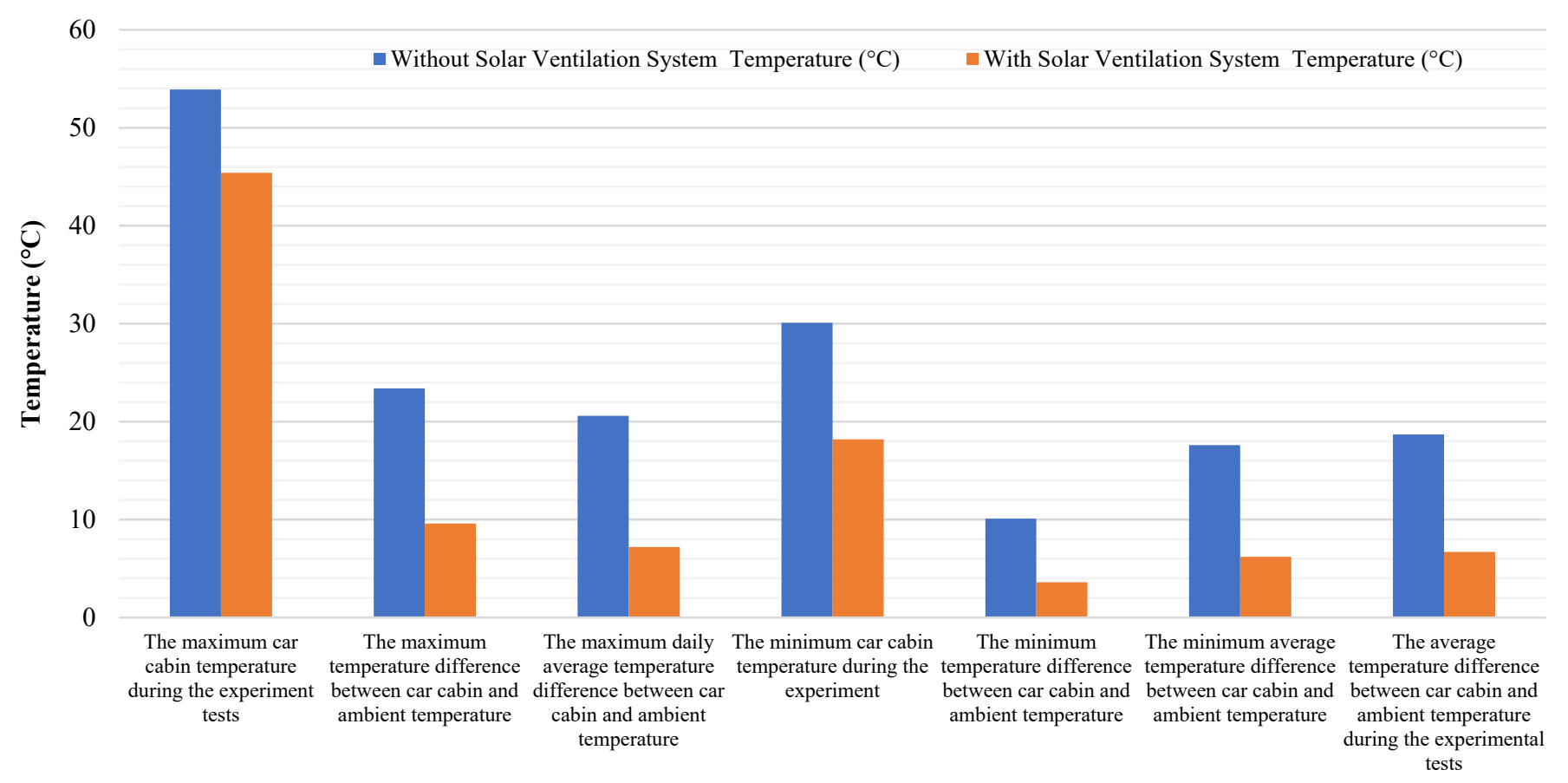

Figure 13. Comparison of experimental results.

\subsection{Proposed System Results Comparing with Similar Works in Different Countries}

Table 6 shows similar works in different countries, and this table can provide the similar works locations and the main results. Therefore, the below table provides an idea of the proposed system performance. The differences in results between the systems are due to many reasons such as the system main components size (solar panel, ventilation fan, and battery), the experiment location's effect on the greenhouse phenomena and system size, the solar radiation, and the climate.

Table 6. Proposed System Results Comparing with Similar Works in Different Countries.

\begin{tabular}{|c|c|c|c|}
\hline Reference & Location & Year & Main Result \\
\hline Proposed system & Jordan & 2021 & $\begin{array}{l}\text { The average temperature reduction } 12.0^{\circ} \mathrm{C} \text { and } \\
\text { temperature percentage reduction is } 64 \% \text {. }\end{array}$ \\
\hline [28] & Malaysia & 2009 & Temperature reduction is almost $7^{\circ} \mathrm{C}$. \\
\hline [31] & Thailand & 2012 & Replace car cabin hot air by ambient cold fresh air. \\
\hline [36] & Malaysia & 2015 & Average temperature reduction is around $15^{\circ} \mathrm{C}$. \\
\hline [37] & Oman & 2015 & Average temperature reduction is around $10^{\circ} \mathrm{C}$. \\
\hline [22] & China & 2015 & Maximum temperature reduction is around $15^{\circ} \mathrm{C}$. \\
\hline [38] & China & 2015 & $\begin{array}{l}\text { The temperature inside the vehicle cabin higher than } \\
\text { the highest environmental temperature by } 5 \text { to } 10^{\circ} \mathrm{C} \text {. }\end{array}$ \\
\hline [39] & UAE & 2016 & Average temperature reduction is $4^{\circ} \mathrm{C}$. \\
\hline$[40]$ & Korea & 2017 & Thermal comfort improvement by $20 \%$. \\
\hline [41] & Malaysia & 2017 & Average temperature reduction is around $10{ }^{\circ} \mathrm{C}$. \\
\hline$[42]$ & China & 2017 & Average temperature reduction is around $4.2^{\circ} \mathrm{C}$. \\
\hline [44] & Malaysia & 2018 & Reduction in the inside temperature about $12 \%$ \\
\hline
\end{tabular}

\section{Conclusions}

A solar ventilation system inside the automobile was created and evaluated. The temperature inside the automobile cabin when parked in the sun was discovered to be substantially higher than the ambient temperature due to the greenhouse effect, according 
to the results of the experimental inquiry. The experimental results taken for the vehicle with and without the solar ventilation system indicate that the maximum daily average temperature differences during the experimental tests between the vehicle cabin and atmosphere temperature with and without the used system were $7.2{ }^{\circ} \mathrm{C}$ and $20.6{ }^{\circ} \mathrm{C}$, respectively. The maximum vehicle cabin temperatures during the experiment tests with and without used system were $45.4^{\circ} \mathrm{C}$ and $53.9^{\circ} \mathrm{C}$, respectively, whereas the minimum average differences in temperature between the vehicle cabin and atmosphere temperature with and without the used system were $6.2^{\circ} \mathrm{C}$ and $17.6^{\circ} \mathrm{C}$, respectively. The minimum car cabin temperatures during the experiment with and without the used system were $18.2^{\circ} \mathrm{C}$ and $30.1^{\circ} \mathrm{C}$, respectively. The average temperature differences between the vehicle cabin and atmosphere temperature during the experimental tests with and without the used system were $6.2{ }^{\circ} \mathrm{C}, 18.7^{\circ} \mathrm{C}$ respectively. Thus, this study confirmed that the proposed system is effective. It may be deduced from the foregoing experimental inquiry that:

- This product will be very effective in reducing the car cabin temperature, due to running when the temperature reaches the set point that is entered on the ventilation controller and that the system will continuously ventilate air until a reduction in the temperature to the set point;

- The AC compressor power could be decreased by about $49 \%$, which means an increase in fuel savings (by about increasing $1 \mathrm{~km} / \mathrm{L}$ ) and reduction in the emissions due to the fact that running of the AC could be reduced near to the half;

- This system will save the children or pets left in vehicles parked under the sun, as many deaths are reported around the world due to the greenhouse effect occurring in car cabins. This product will also save energy, reduce environmental pollution, protect the car interior such as plastic accessories and leather seats, minimize the danger to human health, protect the car cabin, and reduce the car engine load through reducing the AC load.

Finally, our recommendations for future work are concentrated on utilizing a special mechanism with PV panels on the front car glass to create shade and reduce the greenhouse effect.

Author Contributions: H.A.-R., A.O.H., H.A.A.-S., M.A.-D., M.R.G. and H.R. has equal contribution for this manuscript. All authors have read and agreed to the published version of the manuscript.

Funding: This research received no external funding.

Institutional Review Board Statement: Not applicable.

Informed Consent Statement: Not applicable.

Data Availability Statement: Not applicable.

Acknowledgments: The authors acknowledge the support of King Fahd University of Petroleum \& Minerals, Saudi Arabia.

Conflicts of Interest: The authors declare no conflict of interest. 


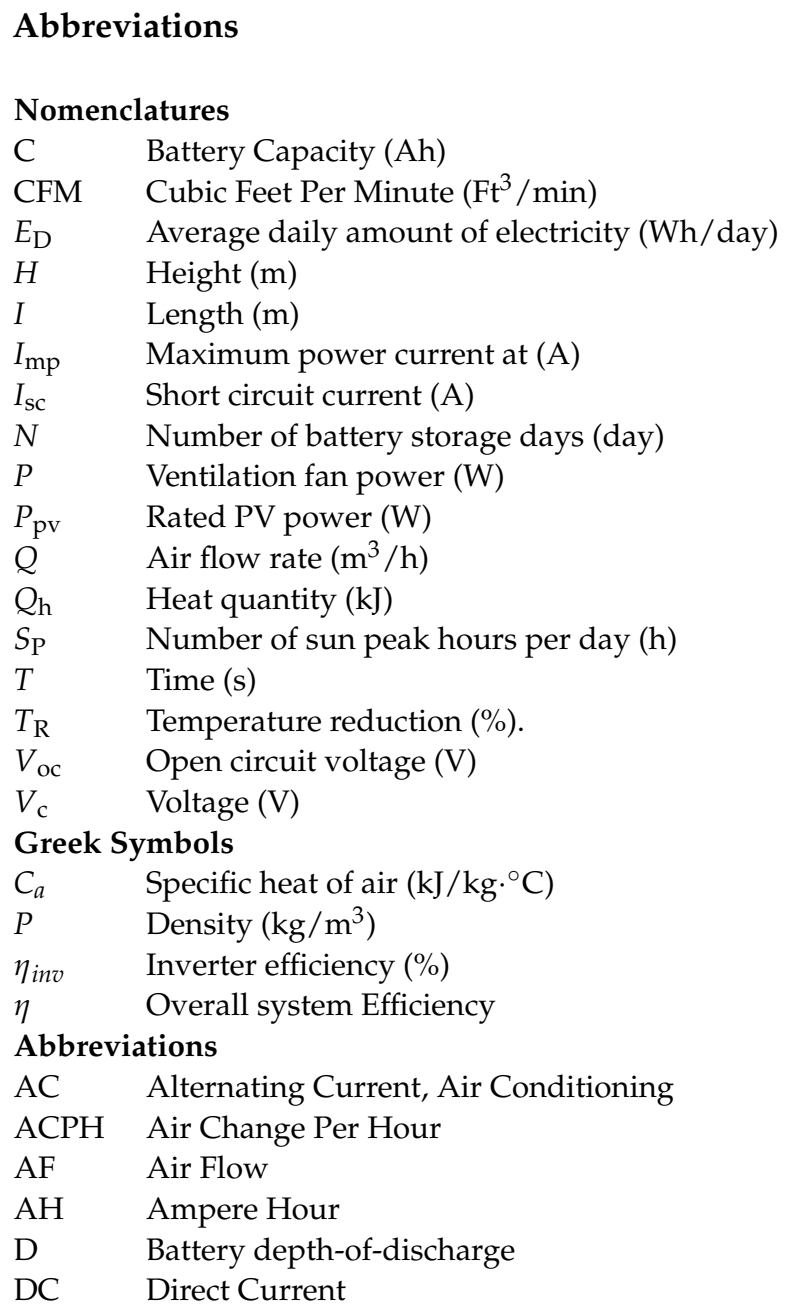

\section{References}

1. Zhou, G.; Ou, X.; Zhang, X. Development of electric vehicles use in China: A study from the perspective of life-cycle energy consumption and greenhouse gas emissions. Energy Policy 2013, 59, 875-884. [CrossRef]

2. Pang, W.; Yu, H.; Zhang, Y.; Yan, H. Solar photovoltaic based air cooling system for vehicles. Renew. Energy 2019, 130, 25-31. [CrossRef]

3. Fazelpour, F.; Vafaeipour, M.; Rahbari, O.; Rosen, M.A. Intelligent optimization to integrate a plug-in hybrid electric vehicle smart parking lot with renewable energy resources and enhance grid characteristics. Energy Convers. Manag. 2014, 77, $250-261$. [CrossRef]

4. Zhang, T.; Feng, Y.; Wu, X.; Pan, Y.; Zhang, Z.; Yuan, Y. A High-Efficiency, Portable, Solar-Powered Cooling System Based on a Foldable-Flower Mechanism and Wireless Power Transfer Technology for Vehicle Cabins. Energy Technol. 2020, 8. [CrossRef]

5. Zhang, Z.; Zhang, X.; Rasim, Y.; Wang, C.; Du, B.; Yuan, Y. Design, modelling and practical tests on a high-voltage kinetic energy harvesting $(\mathrm{EH})$ system for a renewable road tunnel based on linear alternators. Appl. Energy 2016, 164, 152-161. [CrossRef]

6. Lee, J.; Choi, B. Development of a piezoelectric energy harvesting system for implementing wireless sensors on the tires. Energy Convers. Manag. 2014, 78, 32-38. [CrossRef]

7. Gomaa, M.R.; Rezk, H.; Mustafa, R.J.; Al-Dhaifallah, M. Evaluating the Environmental Impacts and Energy Performance of a Wind Farm System Utilizing the Life-Cycle Assessment Method: A Practical Case Study. Energies 2019, 12, 3263. [CrossRef]

8. Gomaa, M.R.; Mustafa, R.J.; Al-Dhaifallah, M.; Rezk, H. A low-grade heat Organic Rankine Cycle driven by hybrid solar collectors and a waste heat recovery system. Energy Rep. 2020, 6, 3425-3445. [CrossRef]

9. Gomaa, M.R.; Rezk, H. Passive cooling system for enhancement the energy conversion efficiency of thermo-electric generator. Energy Rep. 2020, 6, 687-692. [CrossRef]

10. Gomaa, M.R.; Hammad, W.; Al-Dhaifallah, M.; Rezk, H. Performance enhancement of grid-tied PV system through proposed design cooling techniques: An experimental study and comparative analysis. Sol. Energy 2020, 211, 1110-1127. [CrossRef]

11. Gomaa, M.R.; Al-Dhaifallah, M.; Alahmer, A.; Rezk, H. Design, Modeling, and Experimental Investigation of Active Water Cooling Concentrating Photovoltaic System. Sustainability 2020, 12, 5392. [CrossRef] 
12. Gomaa, M.R.; Mohamed, M.A.; Rezk, H.; Al-Dhaifallah, M.; Al shammri, M.J. Energy Performance Analysis of On-Grid Solar Photovoltaic System- a Practical Case Study. Int. J. Renew. Energy Res. 2019, 9, 1292-1301.

13. Gomaa, M.R.; Ahmed, M.; Rezk, H. Temperature distribution modeling of PV and cooling water PV/T collectors through thin and thick cooling cross-fined channel box. Energy Rep. 2021, 8, 1144-1153. [CrossRef]

14. Hasan, A.O.; Osman, A.I.; Al-Muhtaseb, A.H.; Al-Rawashdeh, H.; Abu-Jrai, A.; Ahmad, R.; Gomaa, M.R.; Deka, T.J.; Rooney, D.W. An experimental study of engine characteristics and tailpipe emissions from modern DI diesel engine fuelled with methanol/diesel blends. Fuel Process. Technol. 2021, 220, 106901. [CrossRef]

15. Gomaa, M.R.; Al-Dmour, N.; Al-Rawashdeh, H.A.; Shalby, M. Theoretical model of a fluidized bed solar reactor design with the aid of MCRT method and synthesis gas production. Renew. Energy 2019, 148, 91-102. [CrossRef]

16. Gomaa, M.R.; Mustafa, R.J.; Al-Dmour, N. Solar thermochemical conversion of carbonaceous materials into syngas by CoGasification. J. Clean. Prod. 2020, 248, 119185. [CrossRef]

17. Mekhilef, S.; Saidur, R.; Safari, A. A review on solar energy use in industries. Renew. Sustain. Energy Rev. 2011, 15, 1777-1790. [CrossRef]

18. Gugulothu, R.; Somanchi, N.S.; Banoth, H.B.; Banothu, K. A Review on Solar Powered Air Conditioning System. Procedia Earth Planet. Sci. 2015, 11, 361-367. [CrossRef]

19. Anis, W.R.; Metwally, H.H.B.; El-Samahy, A.E.S.M. Microprocessor-based overcurrent protection for PV powered air-conditioning system. Energy Convers. Manag. 1997, 38, 29-37. [CrossRef]

20. Porumb, R.; Porumb, B.; Bălan, M. Baseline Evaluation of Potential to Use Solar Radiation in Air Conditioning Applications. Energy Procedia 2016, 85, 442-451. [CrossRef]

21. Rugh, J.P.; Chaney, L.; Lustbader, J.; Meyer, J.; Fax, T. Reduction in vehicle temperatures and fuel use from cabin ventilation, solar-reflective paint, and a new solar-reflective glazing. In Proceedings of the 2007 SAE World Congress, Detroit, MI, USA, 16-19 April 2007. Available online: http: / / citeseerx.ist.psu.edu/viewdoc/download?doi=10.1.1.414.1412\&rep=rep1\&type=pdf (accessed on 6 December 2021).

22. Hu, Z.; Tan, G.; Li, Z.; Xu, H.; Huang, W.; Ye, Y. Solar Powered Vehicle Parking Ventilation System Pre-Cooling Analysis; SAE Technical Paper 2015-01-0367; SAE International: Warrendale, PA, USA, 2015. [CrossRef]

23. Huang, K.; Tzeng, S.-C.; Ma, W.-P.; Wu, M.-F. Intelligent solar-powered automobile-ventilation system. Appl. Energy 2005, 80, 141-154. [CrossRef]

24. Ajid, A.B. Solar Powered Exhaust Fan for Automobiles. 2008. Available online: https://core.ac.uk/download/pdf/301115813.pdf (accessed on 1 February 2021).

25. McLaren, C.; Null, J.; Quinn, J. Heat Stress from Enclosed Vehicles: Moderate Ambient Temperatures Cause Significant Temperature Rise in Enclosed Vehicles. Pediatrics 2005, 116, e109-e112. [CrossRef]

26. Global Solar Atlas. 2021. Available online: https://globalsolaratlas.info/map?s=30.448674,36.386719\&m=site\&pv=small,180,30,1 $\& c=11.609193,8.4375,3$ (accessed on 7 February 2021).

27. Mezrhab, A.; Bouzidi, M. Computation of thermal comfort inside a passenger car compartment. Appl. Therm. Eng. 2006, 26, 1697-1704. [CrossRef]

28. Saidur, R.; Masjuki, H.H.; Hasanuzzaman, M. Performance of an improved solar car ventilator. Int. J. Mech. Mater. Eng. 2009, 4, 24-34.

29. Grundstein, A.; Meentemeyer, V.; Dowd, J. Maximum vehicle cabin temperatures under different meteorological conditions. Int. J. Biometeorol. 2009, 53, 255-261. [CrossRef]

30. Bhatti, U. 2011 IEEE Student Conference on Research and Development (SCOReD 2011). Available online: https://www. proceedings.com/14004.html (accessed on 11 December 2021).

31. Ranamuka, D.; Agalgaonkar, A.P.; Muttaqi, K. Preface. Energy Procedia 2012, 14, 931-936. [CrossRef]

32. Jasni, M.A.; Nasir, F.M. Experimental comparison study of the passive methods in reducing car cabin interior temperature. In Proceedings of the International Conference on Mechanical, Automobile and Robotics Engineering (ICMAR'2012), Penang, Malaysia, 11-12 February 2012; pp. 229-233. Available online: http://psrcentre.org/images/extraimages/26.\%20212134.pdf (accessed on 1 January 2021).

33. Ciocanea, A.; Buretea, L.D. Cabin heat removal from parked cars. Mag. Hydraul. Pneum. Tribol. Ecol. Sens. Mechatron. 2014, 3, 52-58.

34. Mohammed, I.; Aljubury, A.; Farhan, A.A.; Mussa, A. Experimental Study of Interior Temperature Distribution Inside Parked Automobile Cabin. J. Eng. 2015, 21, 1-10.

35. Al-kayiem, H.H. Study on the Thermal Accumulation and Distribution Inside a Parked Car Cabin Parked Car Cabin. Am. J. Appl. Sci. 2010, 7, 784-789. [CrossRef]

36. Mohd-Mokhtar, R.; Roslan, A. Sizing, Positioning and Air Ducting Analysis for Solar-Based Car Ventilator. ARPN J. Eng. Appl. Sci. 2015, 10, 9866-9871.

37. Sudhir, C.V.; Marhoon, J.; Dhali, A. Effect of solar ventilation on air conditioning system performance of the car parked under sun light. ARPN J. Eng. Appl. Sci. 2015, 10, 10618-10626.

38. Wang, C.; Tan, G.; Guo, X.; Tian, Z.; Tian, Z.; Li, J. The Energy Management for Solar Powered Vehicle Parking Ventilation System. SAE Int. J. Passeng. Cars-Electron. Electr. Syst. 2015, 8, 244-254. [CrossRef] 
39. Shams, S.; Poon, K.; Aljunaibi, A.; Tariq, M.; Salem, F.; Ruta, D. Solar powered air cooling for idle parked cars: Architecture and implementation. In Proceedings of the 2015 11th International Conference on Innovations in Information Technology (IIT), Dubai, United Arab Emirates, 1-3 November 2015; pp. 239-243.

40. Khatoon, S.; Kim, M.-H. Human Thermal Comfort and Heat Removal Efficiency for Ventilation Variants in Passenger Cars. Energies 2017, 10, 1710. [CrossRef]

41. Hamdan, N.S.; Radzi, M.F.M.; Damanhuri, A.A.M.; Mokhtar, S.N. Dual direction blower system powered by solar energy to reduce car cabin temperature in open parking condition. J. Phys. Conf. Ser. 2017, 908, 012072. [CrossRef]

42. Pan, H.; Qi, L.; Zhang, X.; Zhang, Z.; Salman, W.; Yuan, Y.; Wang, C. A portable renewable solar energy-powered cooling system based on wireless power transfer for a vehicle cabin. Appl. Energy 2017, 195, 334-343. [CrossRef]

43. Qi, L.; Pan, H.; Zhu, X.; Zhang, X.; Salman, W.; Zhang, Z.; Li, L.; Zhu, M.; Yuan, Y.; Xiang, B. A portable solar-powered air-cooling system based on phase-change materials for a vehicle cabin. Energy Convers. Manag. 2017, 150, 148-158. [CrossRef]

44. Shah, H.N.M.; Kamis, Z.; Abdollah, M.F. Develop and implementation of solar powered ventilation system. Indones. J. Electr. Eng. Comput. Sci. 2018, 12, 1211-1221. [CrossRef]

45. GIS. 2019. Available online: https://solargis.com/maps-and-gis-data/download/world (accessed on 12 March 2021).

46. Climate, J. Weather Averages in Ma'an, “Climate \& Weather Averages in Ma'an, Jordan". 2020. Available online: https: / / www.timeanddate.com/weather/jordan/ma-an/climate (accessed on 13 March 2021).

47. Levinson, R.; Pan, H.; Ban-Weiss, G.; Rosado, P.; Paolini, R.; Akbari, H. Potential benefits of solar reflective car shells: Cooler cabins, fuel savings and emission reductions. Appl. Energy 2011, 88, 4343-4357. [CrossRef] 